\title{
初期せん断を受けた固化処理土の一面せん断特性
}

\section{The Shear Strength Recovery Characteristics of Cement Treated Soil}

\author{
by
}

\section{Tomoro UEDA* and Kiyonobu KASAMA**}

The ground solidification method, which mixes an improvement material such as cement into soft ground, is one of soil improvement technologies. This method has been widely used to improve the bearing capacity and control settlement of the foundation ground. However, there is not much research on the strength recovery characteristics of cement-treated soil that has already damaged during the curing period by external forces such as earthquakes and landslides. In this paper, the recovery characteristics of the shear strength for cement-treated Kawasaki and Kaolin clays were clarified by means of a series of box shear tests and powder X-ray diffraction analysis. As a result, the shear strength recovery depends on the soil type of base material, GGBS content, and the vertical pressure for the box shear test. Cement-treated Kawasaki clay shows a strong shear strength recovery as the range from $7.4 \%$ to $340.8 \%$.

\section{Key words}

Soil improvement, Cement, Clay, Shear strength, X-ray diffraction

\section{1 緒言}

我が国では，軟弱地盤に固化材および補助剤を添加す る固化処理工法が広く利用されてきた。その適用範囲は 構造物や戸建住宅の基礎地盤の改良から，地盤の液状化 対策および土畩污染対策など多岐に渡る。固化材を用い た地盤改良は災害大国である日本の土地利用にとって必 要不可欠であり，今後も高い需要が見込まれる.

固化処理工法で改良された地盤は，地震などの外的要 因による破壊が生じても，継続的に固化材の水和物が生 成されることにより強度を回復させる自己修復効果があ ると報告されている. 既にコンクリート分野では, フライ アッシュなどの混和材を混和したコンクリートの自己修 復現象に関する研究が行われている ${ }^{1), 2)}$. また，地盤工学 の分野でも，微生物の活用により地盤の自己修復性を高 める新たな固化処理工法の検討など 3),4)が行われている. 一方で，養生中に何らかの損傷を受けた固化処理土のそ の後の強度回復に関する既往の研究は未だに少ない.

そこで本論文では，固化処理土の強度回復特性を明ら かにするため，養生中にあらかじめせん断変位を与えた 固化処理粘土に対してせん断試験を行い，初期せん断お よびその後の養生が固化処理粘土の一面せん断特性に及 ぼす影響を調べた。

\section{2 実験概要}

\section{(1) 供試体作製}

母材には川崎粘土とカオリン粘土を用いた．固化材に は普通ポルトランドセメント(太平洋セメント(株)製，以
Table 1 The physical properties of base materials.

\begin{tabular}{c|c|c}
\hline & Kawasaki clay & Kaolin clay \\
\hline $\begin{array}{c}\text { Soil particle density } \rho_{s} \\
\left(\mathrm{~g} / \mathrm{cm}^{3}\right)\end{array}$ & 2.66 & 2.63 \\
\hline Liquid limit $w_{L}(\%)$ & 51.0 & 82.1 \\
\hline Plasticity limit $w_{p}(\%)$ & 25.6 & 34.7 \\
\hline Plasticity index $I_{p}$ & 25.4 & 47.4 \\
\hline
\end{tabular}

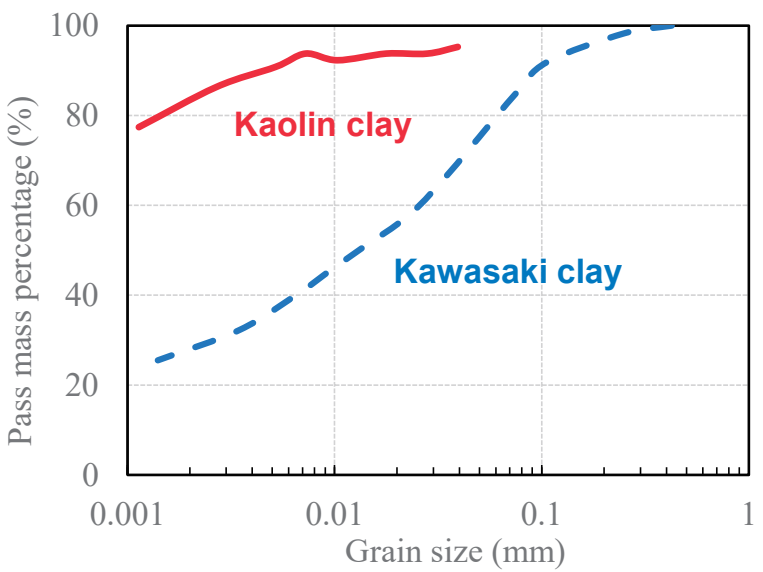

Fig. 1 Grain size distribution curve of base materials.

Table 2 Characteristics of OPC and GGBS.

\begin{tabular}{c|c|c|c}
\hline & $\begin{array}{c}\text { Density } \\
\left(\mathrm{g} / \mathrm{cm}^{3}\right)\end{array}$ & $\begin{array}{c}\text { Blaine } \\
\left(\mathrm{cm}^{2} / \mathrm{g}\right)\end{array}$ & $\begin{array}{c}\text { Mixing rate } \\
(\%)\end{array}$ \\
\hline OPC & 3.16 & 3340 & 10 \\
\hline GGBS & 3.04 & 3750 & $0,5,10$ \\
\hline
\end{tabular}

$\dagger$ 原稿受理 令和 3 年 6 月 10 日 Received June 10, 2021 @2022 The Society of Materials Science, Japan

* 東京工業大学 環境社会理工学院 土木環境工学系 ₹152-0033 東京都目黒区大岡山 Civil and Environmental Eng., Tokyo Inst. of Tech., Meguro-ku, Tokyo 152-0033.

** 九州大学大学院 工学研究院 社会基盤部門 ₹819-0395 福岡市西区元岡744 Department of Civil Eng., Kyusyu Univ., 744 Motooka, Nishi-ku, Fukuoka 819-0395. 
下 OPC) を使用し, 混合率を母材の乾燥重量の $10 \%$ とし た。補助剤には高炉スラグ微粉末 4000 (エスメント関東

（株）製，以下 GGBS）を使用し，混合率を母材の乾燥重 量の $0 ， 5 ， 10 \%$ とした。 Table 1,2,3 および Fig. 1 に以上 の使用材料の物性を示した。

供試体作製は，地盤工学会の定める「安定処理土の締固 めをしない供試体作製方法 (JGS-T821)」5)に準拠して行っ た。両粘土の初期含水比は，目標強度であるせん断強度 $100 \mathrm{kN} / \mathrm{m}^{2}$ が発現するよう， $100 \%$ とした。

(2) 一面せん断試験

固化処理粘土の強度発現が 28 日で終了すると想定し， 供試体には, 養生 7 日目に初期せん断を導入した。また, 初期せん断時に与える水平変位量は，せん断応力の変化 がみられなくなる残留状態までとした.このとき, 水平変 位はおおよそ $2.4 \sim 3.0 \mathrm{~mm}$ となる.

7 日目に初期せん断した供試体は直ちに除荷し，上載圧 はかけずにせん断変位を生じさせたまま 21 日間恒温室で 再養生した. 再養生終了後に 2 次せん断を行い, 一面せん 断強度の変化を調べた。初期せん断および 2 次せん断は 共に，地盤工学会が定める「土の圧密定圧一面せん断試験 方法 (JGS-0561)」6)に準じて行った。せん断試験中の拘束 圧は, 川崎粘土では $100 \mathrm{kN} / \mathrm{m}^{2}$ のみ, カオリン粘土では 50 , $100,150 \mathrm{kN} / \mathrm{m}^{2}$ とした. Table 4 に以上の条件を示した.

(3) 粉末 $X$ 線回折

固化処理粘土内で生成される水和生成物と強度回復特 性の関係を調べるために，セメント 10 \%とスラグ混合率 $10 \%$ の固化処理川崎粘土およびカオリン粘土のせん断試 験後の供試体のせん断面から試料を採取した。試料を粉 砕し乾燥したものを対象に粉末 $\mathrm{X}$ 線回折を行い (以下 $\mathrm{XRD)}$, せん断面に存在する化合物の同定および定量を行 った.

分析には多目的粉末 X 線回折装置 MiniFlex(リガク製) を用いた. 測定条件は, ターゲット $\mathrm{CuK} \alpha$ ，管電圧 $45 \mathrm{kV}$, 管電流 $200 \mathrm{~mA}$ で動作させ, 走査範囲 2 $80^{\circ}$ (2 $\theta$ ), ステッ プ幅 $0.01^{\circ}$ ，走查速度は $5^{\circ} / \mathrm{min} ， と し た 。$ 結晶相の同定 の際には，OPC および GGBS 内に含まれるクリンカー鉱 物および水和反応により生成される物質を対象とし, 統 合粉末 X 線解析ソフトウェア PDXL2 を用いた. 次に, 確 認されたクリンカー鉱物および水和生成物を対象に, RIR 法を用いたリートベルト解析を行うことで生成物の定量 を行った。

\section{3 実験結果と考察}

（1） せん断応力と垂直変位および水平変位の関係

Fig.2 に，セメント $10 \%$ とスラグ混合率 $0 \%$ とした川 崎粘土およびカオリン粘土を拘束圧 $100 \mathrm{kN} / \mathrm{m}^{2}$ で一面せ ん断した場合のせん断応力の変化を示寸.

Fig.2 (a) の川崎粘土の場合，初期せん断供試体には，水 平変位 $2.63 \mathrm{~mm}$ まで初期せん断を行い, 再養生後に 2 次 せん断を行ったところ，せん断応力には再びピークが生 じた．そのピーク強度は初期せん断ピーク強度を上回り，
28 日せん断ピーク強度に近い值をとった。このことから， 固化処理川崎粘土に養生 7 日目に初期せん断を与えると, 21 日間の再養生により強度が回復し，初期せん断残留強 度と 28 日せん断ピーク強度の中間の值をとることが確認 された。

Fig.2 (b) のカオリン粘土では水平変位 $2.64 \mathrm{~mm}$ まで初 期せん断を与えた。川崎粘土同様，2 次せん断応力にはピ ークが生じ，その強度は初期せん断残留強度を上回った が，7 日せん断および 28 日せん断ピーク強度よりは小さ かった. よって, 固化処理カオリン粘土に初期せん断を与 え再養生すると, 強度回復は生じるが, その程度は川崎粘 土と比較して小さいといえる.

Table 3 Chemical composition of OPC (mass \%).

\begin{tabular}{|c|c|c|c|c|c|}
\hline $\mathrm{SiO}_{2}$ & $\mathrm{Al}_{2} \mathrm{O}_{3}$ & $\mathrm{Fe}_{2} \mathrm{O}_{3}$ & $\mathrm{CaO}$ & $\mathrm{MgO}$ & $\mathrm{SO}_{3}$ \\
\hline 17.5 & 4.6 & 2.9 & 66.5 & 1.2 & 2.9 \\
\hline \multicolumn{6}{|c|}{ Table 4 Experimental condition. } \\
\hline \multicolumn{2}{|c|}{ Base material } & \multicolumn{2}{|c|}{ Kawasaki clay } & \multicolumn{2}{|c|}{ Kaolin clay } \\
\hline \multicolumn{2}{|c|}{$\begin{array}{l}\text { Initial water } \\
\text { content } w_{i}\end{array}$} & \multicolumn{4}{|c|}{$100 \%$} \\
\hline \multicolumn{2}{|c|}{$\begin{array}{c}\text { Solidifying } \\
\text { material }\end{array}$} & \multicolumn{4}{|c|}{$\begin{array}{c}\text { Ordinary Portland Cement (OPC) } \\
=10 \%\end{array}$} \\
\hline \multicolumn{2}{|c|}{$\begin{array}{c}\text { Auxiliary } \\
\text { material }\end{array}$} & \multicolumn{4}{|c|}{$\begin{array}{c}\text { Ground- Granulated Blast-furnace Slag } \\
(\text { GGBS })=0,5,10 \%\end{array}$} \\
\hline \multicolumn{2}{|c|}{$\begin{array}{l}\text { Day of } \\
\text { initial shear }\end{array}$} & \multicolumn{4}{|c|}{ Day 7} \\
\hline \multicolumn{2}{|c|}{$\begin{array}{c}\text { Displacement of } \\
\text { initial shear }\end{array}$} & \multicolumn{4}{|c|}{$3 \mathrm{~mm}$} \\
\hline \multicolumn{2}{|c|}{ vertical pressure } & $100 \mathrm{kN} / \mathrm{m}$ & \multicolumn{3}{|c|}{$50,100,150 \mathrm{kN} / \mathrm{m}^{2}$} \\
\hline
\end{tabular}

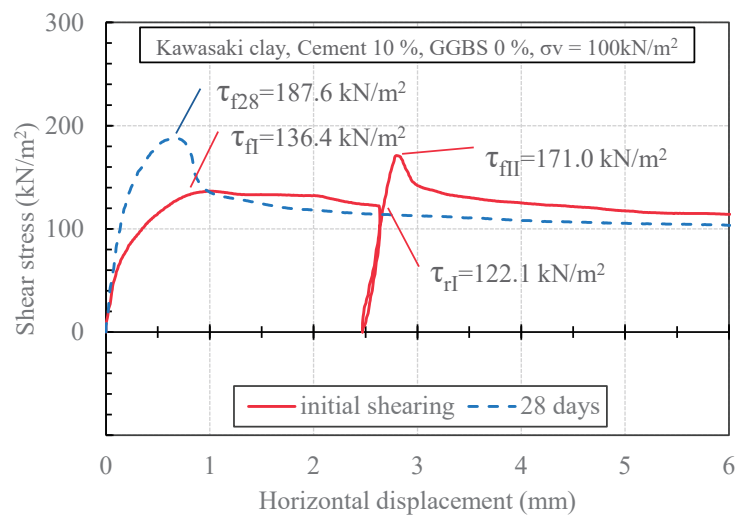

(a) Kawasaki clay

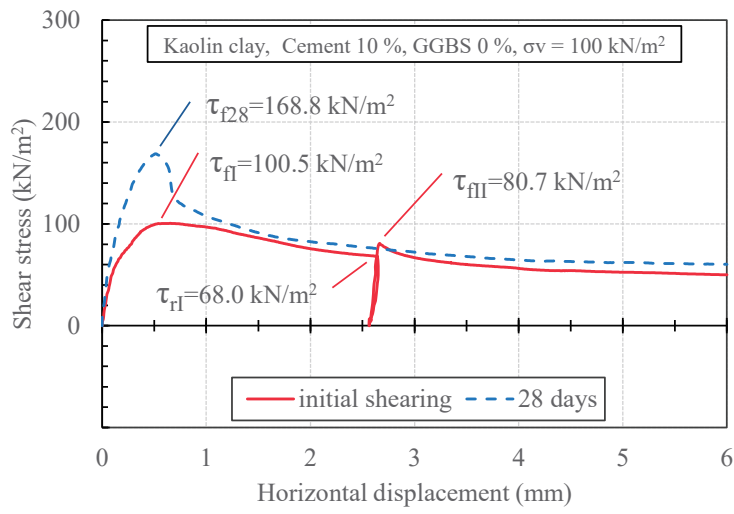

(b) Kaolin clay

Fig. 2 The relationship between shear stress and horizontal displacement of cement treated soil. 
Table 4 Evaluation index.

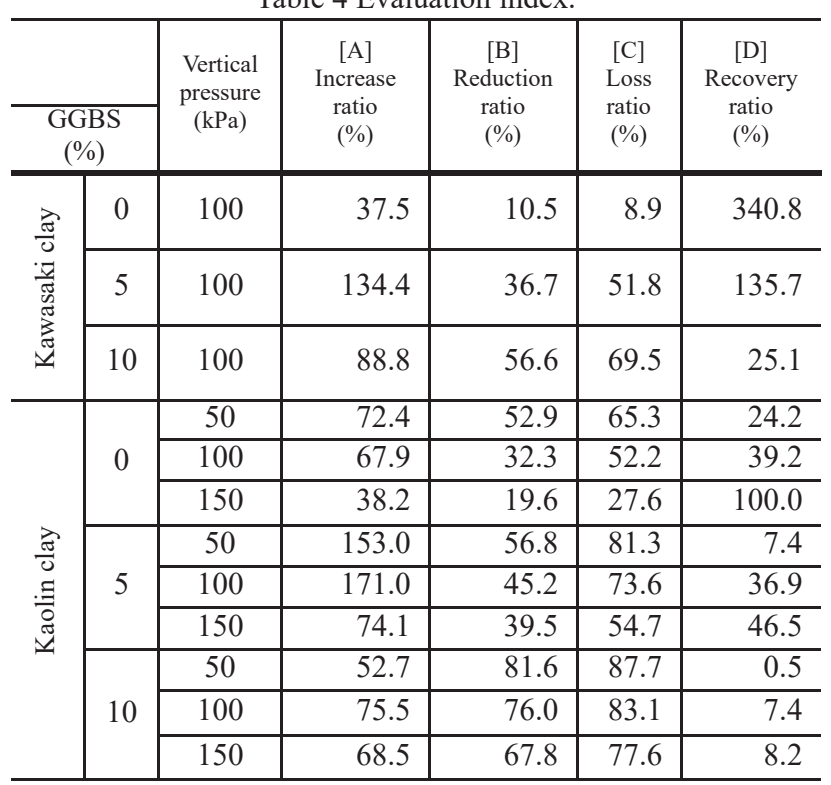

（2）強度回復の指標

初期せん断と強度回復の関係を調べるため, 中村ら ${ }^{7) の ~}$ 研究を参考に, [初期せん断ピーク強度 : $\left.\tau_{f I}\right]$ ，[初期せ ん断残留強度 : $\left.\tau_{r_{I}}\right]\left[2\right.$ 次せん断ピーク強度 : $\left.\tau_{f I I}\right][28$ 日 せん断ピーク強度 : $\tau_{f 28}$ ]これらの值を用い, 以下の強度 回復指標を計算した。

$\mathrm{A} ：$ 強度伸び率

$$
\left(\frac{\tau_{f 28}}{\tau_{f I}}-1\right) \times 100(\%)
$$

初期せん断を与えない通常の養生で，7 日目から 28 日 目せん断強度の増加量を表す指標である。この指標が大 きいほど，7 日目から 28 日目までの強度増進が大きいこ とを示す.

$\mathrm{B}$ : 強度低下率

$$
\left(1-\frac{\tau_{r I}}{\tau_{f I}}\right) \times 100(\%)
$$

初期せん断のピーク状態を基準に，残留状態に移行す るまでどの程度せん断応力の低下が生じたかを表す指標 である.この指標が大きいほど，ピーク後の強度低下が大 きく，ぜい性的な破壊が進行していることを示す。 $\mathrm{C}:$ 強度欠損率

$$
\left(1-\frac{\tau_{f I I}}{\tau_{f 28}}\right) \times 100(\%)
$$

初期せん断を与えない 28 日強度を基準に，初期せん断 を与えた場合の 28 日強度の低下量を表す指標である。こ の指標が $100 \%$ に近いほど, 初期せん断を与えた場合の 28 日強度が，初期せん断を与えない場合の 28 日強度ほどに 回復していないこと示す.

$\mathrm{D}$ : 強度回復率

$$
\frac{\tau_{f I I}-\tau_{r I}}{\tau_{f I}-\tau_{r I}} \times 100(\%)
$$

再養生期間中の強度増加分を分子，初期せん断時のピ 一ク強度と残留強度の差を分母とし, 強度回復率とした。 この指標が大きいほど，初期せん断時のせん断量に対す るその後の強度回復具合が大きいことを表している。

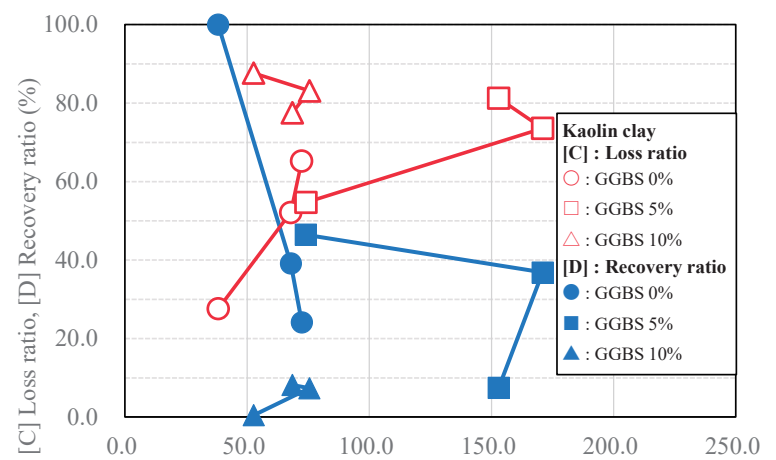

[A] Increase ratio (\%)

(a) The case of setting increase ratio to horizontal axis

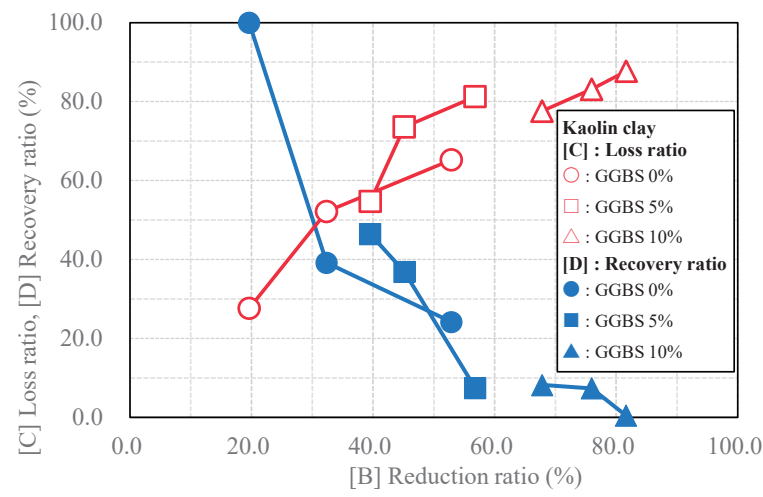

(b) The case of setting reduction ratio to horizontal axis Fig. 3 The relationship of indices $[\mathrm{A}] \sim[\mathrm{D}]$.

Table 4 に各指標の計算結果を示した。 これより，川崎 粘土で最大 $340.8 \%$ となった強度回復率は, 同条件の力 オリン粘土では $39.2 \%$ となることからも, カオリン粘土 の方が全体的に小さい值を取ると言える. 母材の種類, せ ん断時の拘束圧および GGBS 混合率に值が大きく左右さ れる結果となったが, とりわけGGBS 混合率については, 混合率が増加する程に欠損率が増加し回復率が低下する 結果となった。これは, 混合率が増加すると 28 日せん断 ピーク強度は著しく増加する一方, 2 次せん断ピーク強度 はほとんど変化しないためであり, 以上より GGBS は初 期せん断後の再養生による強度回復に寄与しないと推測 される。

また，指標間の関係を検討するために，Fig.3 に，セメ ント $10 \%$ で固化処理したカオリン粘土について, 横軸を 強度伸び率または強度低下率，縦軸を強度欠損率および 強度回復率とした関係図を示した。 Fig.3 (a)より, 強度伸 び率と強度欠損率, 強度回復率の間には相関は見られな いが, Fig.3 (b)では, 強度低下率が増加するほど, 強度欠 損率が増加し, 強度回復率が低下寸る傾向にある. 上記の ように回復率が伸び率よりも低下率に左右されるという ことは, 固化処理土の強度回復は, 通常の養生による強度 増進の程度とは関係がなく, むしろ初期せん断時のピー ク強度と残留強度の差に依存して決まると考えられる。

(3) クーロンの破壊規準

Fig.4 に，固化処理カオリン粘土（セメント $10 \%$ ，スラ グ混合率 $0 \%$ ）の一面せん断試験結果から求めたクーロン の破壊規準をピーク状態, 残留状態ごとに示した. 


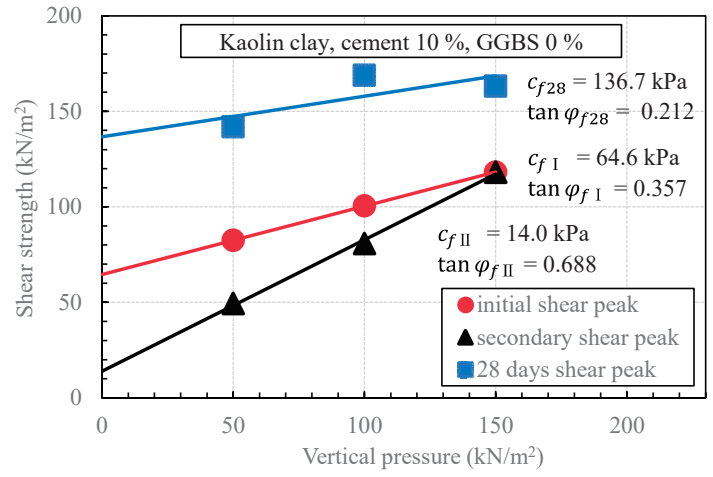

(a) Peak state

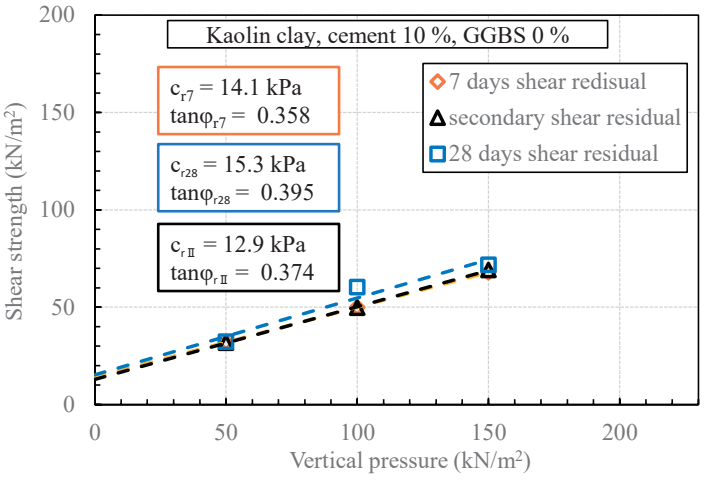

(b) Residual state

Fig.4 Mohr-Coulomb yield criterion of cement treated Kaolin clay with GGBS $0 \%$.

Fig.4 (a) より,初期せん断を与えない場合は，ピーク状 態の破壊規準において 7 日せん断から 28 日せん断の間で 粘着力が大きく増加した。 これは養生に伴い固化材の水 和反応が進行するためである。しかし，初期せん断を与え た場合，粘着力が減少する一方で内部摩擦角が大きく増 加する結果となった. Fig.4 (b) は残留状態のモール・クー ロンの破壊規準を示したものである。ここではそれぞれ のせん断段階においてほとんど変化は生じなかった。

以上より 7 日目から 28 日目の養生では，初期せん断を 与えなければ粘着力成分が増加し，初期せん断を与える と内部摩擦角成分が増加すると考えられる.

(4) 粉末 X 線回折によるせん断面の成分分析

Fig.5に，固化処理川崎粘土（セメント $10 \%$ ，スラグ混 合率 $10 \%$ ）のせん断試験直後（拘束圧 $100 \mathrm{kN} / \mathrm{m}^{2}$ ) に行っ たXRDの結果を示した．表中には，各化合物の質量比が 示されている. トリンガイトとアルミン酸カルシウム水 和物，はともにセメントの水和反応による生成物であり， すなわち, 初期せん断を与えた以降でも, せん断面におい てセメントの水和反応は継続しており，せん断強度の回 復をもたらしたと考えられる。

\section{4 結論}

本論文で得られた成果を以下にまとめる.

養生 7 日目に初期せん断を与え，21 日間再養生した固 化処理供試体には，再養生によって強度回復が生じた。 回復指標は供試体の母材の種類，せん断時拘束圧，スラ グ混合率によって異なった.

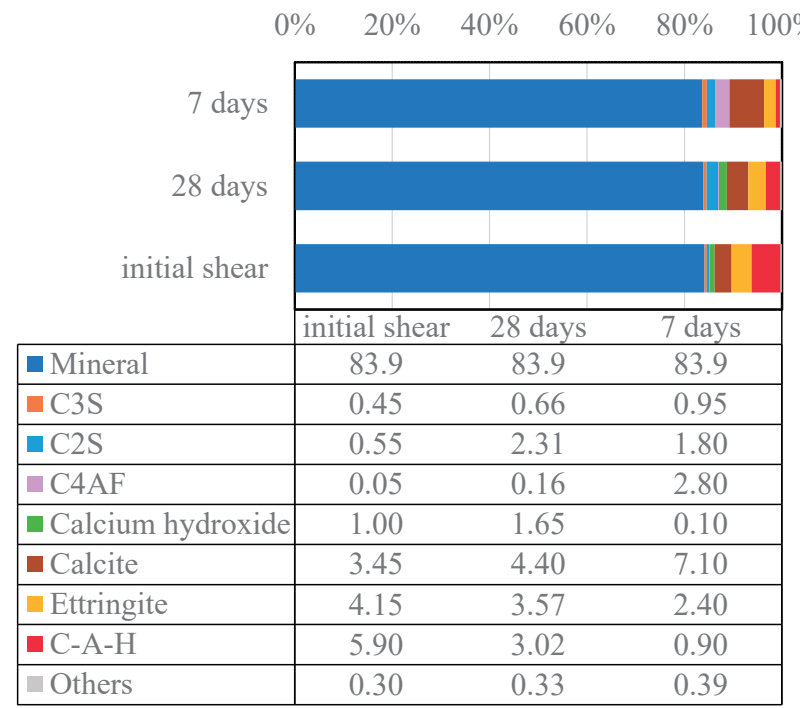

Fig.5 Mass ratio of each compound by XRD.

スラグ混合率が大きいほじ，強度欠損率が大きく強度 回復率が小さい。これは, スラグ混合率が再養生中の強 度増加にほとんど影響しないためであった。

強度の回復は通常の養生による強度増加とは関係がな く, 一方で初期せん断時のピーク強度と残留強度の差に よって決まると考えられる.

破壊規準に着目すると，初期せん断により粘着力成分 が減少し, 再養生することで内部摩擦角成分が増加した。

初期せん断以降でもエトリンガイトおよびアルミン酸 カルシウム水和物の増加が確認され，強度回復の原因と して, 初期せん断後にもセメントの水和反応が活発に行 われていることが考えられる.

\section{参考文献}

1) Na. Seung-hyun, Y. Hama, M. Taniguchi and T. Sagawa, "The self-healing performance of concrete using ground granulated blast-furnace slag and fly ash", Proceedings of the Japan concrete inst, Vol34, No.1, pp.1402-1407, (2012).

2) R. Ueda, J. Kawano, T. Iiboshi and A. Eriguchi, "Influence of dosage of amino acid on self-healing performance of concrete", Cement Science and Concrete Technology, Vol.70, No.1, pp.321-327, (2012).

3) S. Kawasaki, "Present status of ground improvement technologies using microbial functions", Journal of MMIJ, Vol.131, No.5, pp.155-163, (2015).

4) T. Hata, N. Tateno and H. Abe, "Evaluation of coastal region microbial carbonate precipitation using urease produced microorganisms", Japanese Geotechnical Journal, Vol.6, No.2, pp.305-315, (2011).

5) Japanese Geotechnical Society, "Practice for making curing stabilized soil specimens without compaction (JGS 0821-2000)", Laboratory Testing Standards of Geomaterials, pp.426-434, (2009).

6) Japanese Geotechnical Society, "Method for consolidated constant volume direct box shear test on soils (JGS 05602000)", Laboratory Testing Standards of Geomaterials, pp.666-670, (2009).

7) S. Nakamura and S. Gibo, "The recovered strength of landslide soils and its relation to the effective normal stress", Journal of the Japan Landslide Society, Vol.37, No.3, pp.18-24, (2000). 